\title{
Activity and function of the nuclear factor kappaB pathway in human parathyroid tumors
}

\author{
$S$ Corbetta, L Vicentini ${ }^{1}$ S Ferrero ${ }^{2}$, A Lania, G Mantovani, D Cordella ${ }^{3}$, \\ $P$ Beck-Peccoz and A Spada
}

\author{
Institute of Endocrine Sciences, and ${ }^{1}$ Endocrine Surgery, Fondazione Ospedale Maggiore IRCCS, University of Milan, via F Sforza 32 , \\ 21122 Milan, Italy \\ ${ }^{2}$ Pathology Unit, Department of Medicine, Surgery and Dentistry, Azienda Ospedaliera San Paolo, Milan, Italy \\ ${ }^{3}$ Laboratorio Sperimentale di Ricerche Endocrinologiche, Istituto Auxologico Italiano IRCCS, Milan, Italy \\ (Requests for offprints should be addressed to A Spada; Email: anna.spada@unimi.it)
}

\begin{abstract}
Previous studies indicate that nuclear factor kappaB (NF-kB) transcription factor is deregulated and overexpressed in several human neoplasias. The aim of this study was to test the hypothesis that the NF-KB pathway may be involved in parathyroid tumorigenesis. For this purpose, we determined the level of NF-KB activity, evaluated as phosphorylation of the transcription subunit p65, its modulation by specific and non-specific agents and its impact on cyclin D1 expression. Phosphorylated p65 levels present in parathyroid neoplasias $(n=13)$ were significantly lower than those found in normal tissues ( $n=3$; mean optical density (OD) $0.19 \pm 0.1$ vs $0.4 \pm 0.1, P=0.007$ ), but there was no significant difference between adenomas and secondary and multiple endocrine neoplasia type 1 (MEN1)-related hyperplasia. Conversely, MEN2A (Cys634Arg)-related parathyroid samples showed extremely high levels of phosphorylated p65 that exhibited a nuclear localization at immunohistochemistry $(n=3)$. Phosphorylated p65 levels negatively correlated with menin expression $\left(r^{2}=0.42, P=0.05\right)$. Tumor necrosis factor- $\alpha(T N F \alpha)$ caused a significant increase in phosphorylated p65 levels (183 $\pm 13.8 \%$ of basal) while calcium sensing receptor $(\mathrm{CaR})$ agonists exerted a significant inhibition (19.2 $\pm 3.3 \%$ of basal). Although TNF $\alpha$ was poorly effective in increasing cyclin D1 expression, NF- $\mathrm{kB}$ blockade by the specific inhibitor BAY11-7082 reduced FCS-stimulated cyclin D1 by about $60 \%$. Finally, the inhibitory effects of CaR and BAY11-7082 on cyclin D1 expression were not additive - by blocking NF-KB CaR activation did not induce a further reduction in cyclin D1 levels. In conclusion, the study demonstrated that in parathyroid tumors: (1) p65 phosphorylation was dramatically increased by RET constitutive activation and was negatively correlated with menin expression, (2) p65 phosphorylation was increased and reduced by $\mathrm{TNF} \alpha$ and $\mathrm{CaR}$ agonists respectively, and (3) blockade of the NF- $\mathrm{KB}$ pathway caused a significant decrease in cyclin D1 expression.
\end{abstract}

Endocrine-Related Cancer (2005) 12 929-937

\section{Introduction}

The ubiquitous nuclear factor kappa $\mathrm{B}(\mathrm{NF}-\kappa \mathrm{B})$ transcription factor plays a crucial role in immune and inflammatory responses. NF- $\mathrm{KB}$ is a heterodimeric transcription activator consisting of the DNA binding subunit p50 and the transactivation subunit p65/RelA (hereafter referred to as p65) (Delfino \& Walker 1999). In most cells, NF- $\kappa \mathrm{B}$ is sequestered in the cytoplasm bound to its biological inhibitor IKB. A variety of stimuli, such as cytokines, toxins and mitogens, activate the I $\mathrm{KB}$ kinase complex, leading to the degradation of the phosphorylated I $\mathrm{I} B$ and the release and nuclear translocation of NF-KB (Delfino \& Walker 1999). In addition to the involvement in the immune response, NF- $\mathrm{KB}$ serves as a positive mediator of normal cell growth and oncogenesis, consistent with the observation that several human neoplasias, such as breast cancers, hepatocellular carcinomas, micosis fungoides and Hodgkin's disease, are associated with 
NF- $\kappa \mathrm{B}$ deregulation and overexpression (Bargou et al. 1997, Sovak et al. 1997, Izban et al. 2000, Tai et al. 2000). Accordingly, the transcription of the cyclin D1 gene, a key regulator of G1 phase progression, is potently activated by p65 (Guttridge et al. 1999). Moreover, the oncosuppressor gene, menin, that is mutated in multiple endocrine neoplasia (MEN) type 1 syndrome, has recently been reported to interact with $\mathrm{NF}-\kappa \mathrm{B}$ and to inhibit the NF- $\mathrm{B}$-mediated transcriptional activation (Heppner et al. 2001).

Several lines of evidence suggest that both cyclin D1 and menin are strongly involved in parathyroid tumorigenesis (Rosemberg et al. 1991, Bhuyan et al. 2000). The overexpression of cyclin D1 protein as well as the loss of the tumor suppressor function of menin have been demonstrated to induce parathyroid hyperplasia in transgenic mice (Imanishi et al. 2001, Bertolino et al. 2003, Libutti et al. 2003). Moreover, as a consequence of inactivating menin mutations, parathyroid neoplasia develops in almost all patients with MEN1. Parathyroid hyperplasia is also found in $10-25 \%$ of cases of MEN type $2 \mathrm{~A}$, in which mutations of the RET oncogene occur. A possible link between RET gene product and NF- $\kappa \mathrm{B}$ activity has been suggested by the recent demonstration that TT cells, a human medullary thyroid carcinoma cell line expressing the MEN2A and MEN2B type RET oncogene, displayed transcriptionally active p65, its inhibition resulting in cell death (Ludwig et al. 2001).

In the present study, we tested the hypothesis that the NF- $\mathrm{KB}$ pathway may be involved in parathyroid tumorigenesis. In particular, NF- $\kappa \mathrm{B}$ activity, evaluated as phosphorylation of the transcription subunit p65, and its correlation with RET and menin expression, as well as the effects of calcium-sensing receptor agonists on NF- $\mathrm{\kappa B}$ activation and cyclin D1 expression were investigated in human parathyroid tumors.

\section{Materials and methods}

\section{Parathyroid tissues}

The study included 9 biopsies of normal parathyroid glands obtained from normocalcemic patients who underwent surgery for thyroid disease and 21 parathyroid neoplasias (12 adenomas from patients with primary hyperparathyroidism, 3 hyperplasias from patients with hyperparathyroidism secondary to renal failure, 3 hyperplasias from patients with MEN1related hyperparathyroidism and 3 from MEN2A patients). Tissues removed at surgery were in part fixed in $10 \%$ buffered formalin and paraffin embedded for immunohistochemistry (IHC), in part placed in sterile medium for cell culture, and in part snap frozen in liquid nitrogen and stored at $-70^{\circ} \mathrm{C}$ until analysis. All parathyroid tumors were screened for $M E N 1$ and RET gene mutations. DNA was extracted from parathyroid tissues by standard methods. By amplification of exons $10,11,13,14,15$ and 16 of the RET gene and direct sequencing, performed as previously described (Fugazzola et al. 2002), the Cys634Arg mutation was detected in the parathyroid hyperplasias from patients with MEN2A. As far as the menin gene was concerned, the 9 exons of the coding sequence were amplified and direct sequencing revealed three mutations (Arg415stop, Val117stop, Glu474stop) in the parathyroid hyperplasias from patients with MEN1 (primers available on request). The study was approved by the local Ethical Committee and an informed consent was obtained from each patient.

\section{Immunohistochemistry}

Sections from paraffin-embedded tissues were stained with hematoxylin and eosin for routine light microscopy examination. IHC detection of NF- $\kappa \mathrm{B}$ p 65 was carried out using the immunoperoxidase technique. Briefly, tissue sections were dewaxed, rehydrated in xylene/alcohol, and subjected to antigen retrieval by three 6-min microwave cycles in sodium citrate (pH 6.0). Endogenous peroxidase was blocked by incubation for $10 \mathrm{~min}$ with $3 \%$ hydrogen peroxidase in deionized water. Sections were then incubated for $1 \mathrm{~h}$ at room temperature with a rabbit polyclonal antibody against NF- $\mathrm{KB}$ p65 (Zymed Laboratories, Inc., San Francisco, CA, USA) diluted 1:500. Antigen-antibody detection was performed with a peroxidase-conjugated secondary antibody (Envision; DAKO, Carpinteria, CA, USA). Sections were stained with $3,3^{\prime}$-diaminobenzidine substrate and quickly counterstained with hematoxylin. Control sections were obtained by omitting the primary antibody.

\section{Determination of phosphorylated p65 levels in cultured parathyroid cells and tissue samples}

Dispersed parathyroid cells were obtained by enzymatic digestion and cultured at a density of $10^{6}$ cells/ well for $16 \mathrm{~h}$ in HAM-F10 (containing $0.5 \mathrm{mM} \mathrm{Ca}{ }^{2+}$ and $0.5 \mathrm{mM} \mathrm{Mg}^{2+}$ ) (Sigma Chemical, St Louis, MO, USA), supplemented with $10 \%$ heat-inactivated fetal calf serum (FCS) and antibiotics in a humidified atmosphere of $5 \% \quad \mathrm{CO}_{2}$ at $37^{\circ} \mathrm{C}$, as previously described (Corbetta et al. 2000). After $16 \mathrm{~h}$, cell cultures were treated with various reagents, i.e. tumor necrosis factor $\alpha(\mathrm{TNF} \alpha)$, BAY11-7082, gadolinium 
and neomycin (Sigma Chemical) for $30 \mathrm{~min}$ and subsequently placed on ice. The NF- $\kappa \mathrm{B}$ activation was evaluated by detecting phosphorylated $\mathrm{p} 65$ protein in $10 \mu \mathrm{g} /$ well nuclear protein extracts from each cell preparation using the TransAM NF- $\kappa \mathrm{B}$ kit (Active Motif, Rixensart, Belgium). Phosphorylated p65 specifically binds to the immobilized oligonucleotide containing the NF- $\kappa \mathrm{B}$ consensus site (5'-GGGACTTTCC-3'). The primary antibody used to detect $\mathrm{NF}-\kappa \mathrm{B}$ recognized an epitope on $\mathrm{p} 65$ that is accessible only when it is activated and bound to its DNA target. A horseradish peroxidase (HRP)-conjugated secondary antibody provided a sensitive colorimetric readout that was quantified by spectrophotometry at $450 \mathrm{~nm}$. As a positive control, Jurkat nuclear extracts $(2.5 \mu \mathrm{g} /$ well) were used. The same kit was used to assess the levels of phosphorylated p65 in parathyroid tissues $(20 \mu \mathrm{g} /$ well total protein extracts from each tissue sample in duplicate).

\section{Detection of menin protein expression}

Twenty micrograms total proteins extracted from normal and neoplastic parathyroid tissues using Cell Lysis buffer (New England Biolabs, Beverly, MA, USA) supplemented with $200 \mathrm{mM}$ PMSF (Sigma Chemical) and protease and phosphatase inhibitors, were separated by SDS-PAGE at $10 \%$, and transferred to nitrocellulose filters (Transfer Blot, BioRad), as previously described (Corbetta et al. 2002). The filters were subsequently incubated for $3 \mathrm{~h}$ with an affinitypurified goat polyclonal antibody raised against the C-terminal region of the menin protein of human origin (Santa Cruz Biotechnology, Inc., Santa Cruz, CA, USA) diluted $1: 200$, and then with a secondary rabbit anti-goat antibody conjugated to HRP (diluted $1: 2000$ ). The expression of glyceraldeyde-3-phosphate deydrogenase (GAPDH) by a mouse monoclonal anti-GAPDH antibody (Ambion, Ltd., Huntingdon, Cambridgeshire, UK) was used as an internal control for protein loading. The membranes were finally treated with chemiluminescent substrate and enhancer (Pico Western Detection kit; New England Biolabs, Beverly, MA, USA) and exposed to X-ray film for $10 \mathrm{~s}$. The densitometric readings of the resulting bands were evaluated using a BioRad GS-670 imaging densitometer.

\section{Detection of cyclin D1 protein expression}

Dispersed cells $\left(10^{6}\right.$ cells/well) were cultured in HAMF10 (containing $0.5 \mathrm{mM} \mathrm{Ca}^{2+}$ and $0.5 \mathrm{mM} \mathrm{Mg}^{2+}$ ), supplemented with $0.5 \%$ FCS and penicillin/streptomycin in a humidified atmosphere of $5 \% \mathrm{CO}_{2}$ at $37^{\circ} \mathrm{C}$ for $16 \mathrm{~h}$. Subsequent incubations with various reagents were performed in HAM-F10 with $0.1 \%$ bovine serum albumin at $37^{\circ} \mathrm{C}$ for $8 \mathrm{~h}$ and then stopped on ice. Apoptosis was analyzed by examination of cellular morphology, and cellular preparations in which it occurred in more than $10 \%$ of cells were excluded. In the medium, $\mathrm{Ca}^{2+}$ concentrations were controlled by the direct electric potential method (EML-100, Radiometer, Copenhagen, Denmark). The medium was removed and cells were treated with $200 \mu$ ice-cold Cell Lysis buffer (New England Biolabs) supplemented with $200 \mathrm{mM}$ PMSF and protease and phosphatase inhibitors. Cyclin D1 was selectively immunoprecipitated from $100 \mu \mathrm{g}$ total proteins (as detected by the bicinchoninic protein assay) by the specific mouse monoclonal anti-human cyclin D1 antibody (Novocastra Laboratories, Newcastle upon Tyne, UK) and the resulting immunoprecipitates were measured by western blotting, visualized by the chemiluminescent method and evaluated by imaging densitometer, as previously described (Lania et al. 2003). Experiments were repeated at least twice.

\section{Statistical analysis}

Data are presented as the mean \pm standard error (s.E.). Statistical analysis was carried out using the paired or unpaired Student's $t$-test and linear regression analysis as appropriate. A $P$ value of less than 0.05 was considered statistically significant.

\section{Results \\ Evaluation of phosphorylated p65 levels in human parathyroid tissues}

The primary antibody used to detect NF- $\mathrm{KB}$ in frozen tissues recognized an epitope on phosphorylated $\mathrm{p} 65$ that is accessible only when NF- $\kappa \mathrm{B}$ is activated and bound to its DNA target. By using this approach, the levels of phosphorylated p65 present in parathyroid neoplasias $(n=13)$ were significantly lower that those found in normal tissues $(n=3$; mean optical density (OD) $0.19 \pm 0.1$ vs $0.40 \pm 0.1, P=0.007$ ), with no significant difference between adenomas $(n=9)$ and secondary $(n=3)$ and MEN1-related hyperplasia $(n=1) \quad$ (mean OD $0.19 \pm 0.04$ vs $0.20 \pm 0.05$ ). By contrast, parathyroid samples harboring the Cys634Arg RET mutation showed extremely high phosphorylated p65 levels, that doubled those detected in normal parathyroid tissue (Fig. 1). Accordingly, by IHC analysis MEN2A-related hyperplasias $(n=3)$ showed an intense nuclear immunureactivity for $\mathrm{p} 65$ in about $25-30 \%$ of neoplastic cells, that was mainly 


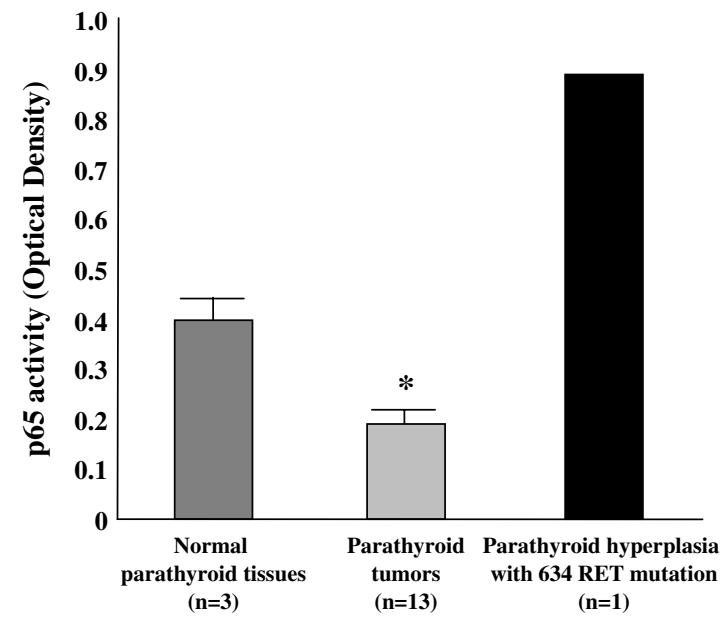

Figure 1 Phosphorylated p65 levels in human parathyroid tissues. Phosphorylated p65 proteins from total protein extracts interact with the specific NF- $\kappa B$ DNA consensus site $5^{\prime}$-GGGACTTTCC-3'. * $P=0.007$ compared with normal parathyroid tissue.

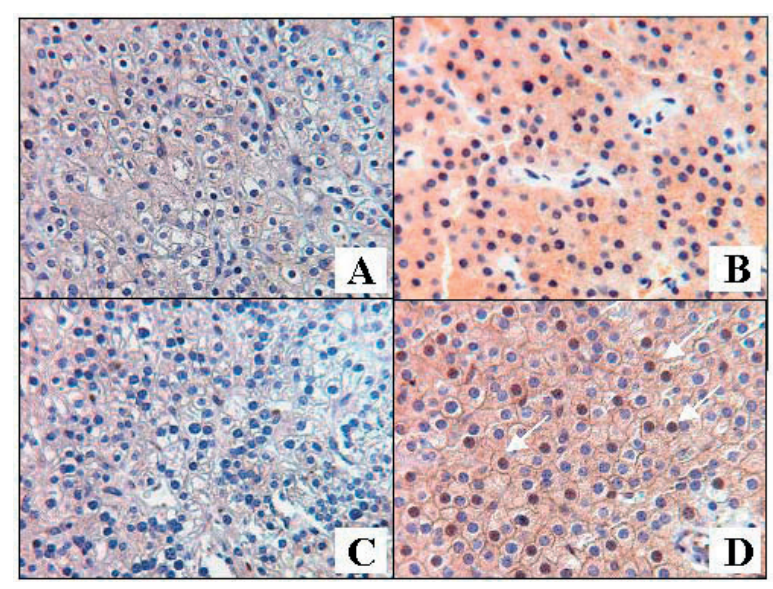

Figure 2 Representative immunostaining for p65 protein in 3 normal parathyroids (A), 9 sporadic parathyroid adenomas (B), 3 MEN1-related hyperplasias (C) and 3 MEN2A-related hyperplasias (D). The immunoreactivity was visualized by diaminobenzidine, positive cells giving a brown color at the site of reaction. Samples in A, B and C showed only a weak and cytoplasmic positivity for p65. MEN2A-related hyperplasia (D) showed an intense and nuclear immunopositivity (arrows) in almost $25-30 \%$ of cells, indicative of p65 phosphorylation, activation and nuclear translocation. Photomicrographs are shown at 20x magnification.

localized in the nucleus, consistent with the nuclear translocation of the phosphorylated NF- $\kappa$ B. By contrast, cells from normal and neoplastic parathyroids showed a weak to moderate immunoreactivity that was restricted to the cytoplasm (Fig. 2).
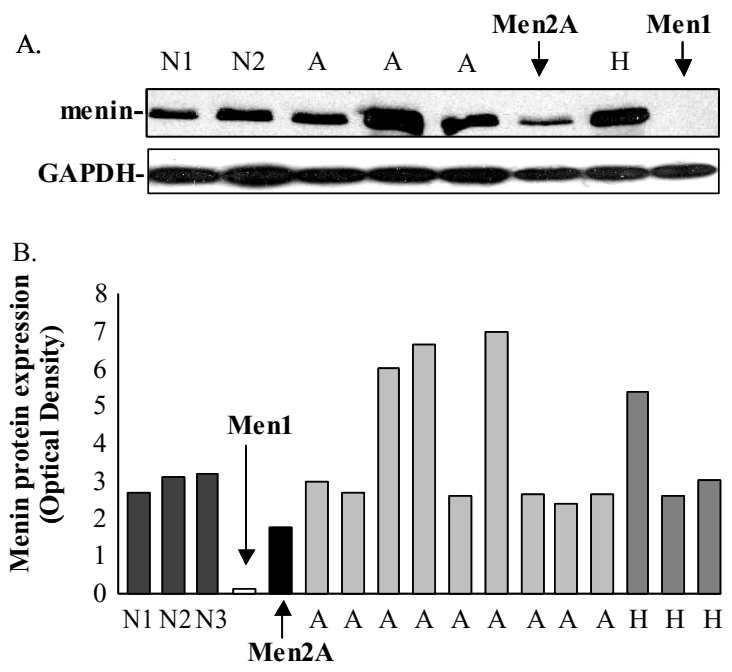

Figure 3 (A) Representative immunoblot of menin protein expression in human parathyroid tissues. A goat polyclonal antibody raised against the C-terminal region of the menin protein of human origin was employed to detect a band of $67 \mathrm{kDa}$. GAPDH protein expression has been used as an internal control. (B) Menin protein expression in 3 normal parathyroid biopsies and 14 parathyroid tumors. $\mathrm{N}$, normal parathyroid samples; $\mathrm{H}$, parathyroid hyperplasias in hyperparathyroidism secondary to renal failure; $A$, parathyroid adenomas in sporadic primary hyperparathyroidism. Men1, parathyroid hyperplasia in MEN1(Arg415stop)-related primary hyperparathyroidism; Men2A, parathyroid hyperplasia in MEN2A (Cys634Arg)-related primary hyperparathyroidism.

\section{Menin protein expression in parathyroid tissues}

Menin protein expression was evaluated in the same parathyroid tumors that were analyzed for phosphorylated p65. Menin protein was detected in all parathyroid tumors except the one harboring the Arg415stop mutation in the menin gene (Fig. 3). Menin expression levels in parathyroid tumors were highly variable (OD ranging from 1.88 to 6.98) compared with those observed in normal tissues (OD ranging from 2.82 to 3.13). Considering the sporadic parathyroid adenomas and non MEN-related hyperplasia, a negative correlation between phosphorylated p65 levels and menin levels was detected $\left(r^{2}=0.42\right.$, $P=0.05)$, with parathyroid tumors characterized by relatively higher menin expression showing lower phosphorylated p65 levels (Fig. 4).

\section{Modulation of p65 phosphorylation in normal and neoplastic parathyroid cells}

Dispersed cells from normal parathyroids and from non MEN-related tumors showed detectable 


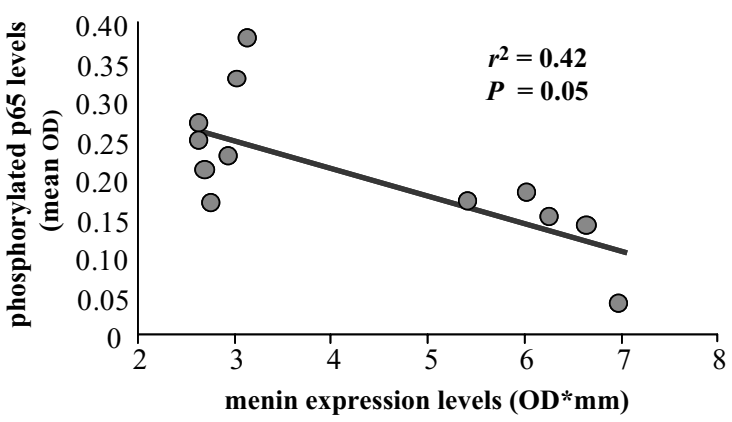

Figure 4 Relationship between phosphorylated p65 levels and menin protein expression levels in the different non-MENrelated parathyroid tumors.

phosphorylated p65 levels. Preincubation with the specific inhibitor BAY11-7082 $(10 \mu \mathrm{M})$, that is known to prevent the phosphorylation of $\mathrm{I} \kappa \mathrm{B} \alpha$ and the subsequent release and activation of $\mathrm{p} 65$, abolished basal phosphorylated p65 levels (Fig. 5). In adenomatous parathyroid cell preparations, 10\% FCS stimulation induced a slight but significant increase in phosphorylated p65 levels. In this condition, a 2-h preincubation with $100 \mathrm{nM}$ phorbol 12-myristate 13-acetate (PMA), a well known NF- $\mathrm{BB}$ activator, induced an increase in phosphorylated p65 levels $(243 \pm 24.7 \%$ of basal levels), suggesting that in parathyroid cells, as in other cell systems, the NF- $\mathrm{BB}$ pathway may be induced through protein kinase $\mathrm{C}$ activation. Similarly, the addition of the cytokine TNF $\alpha(100 \mathrm{ng} / \mathrm{ml})$ induced a significant increase in phosphorylated p65 levels in cell preparations from normal $(287 \pm 24 \%, n=3)$ and tumoral parathyroid tissues (Fig. 5).

As parathyroid hormone secretion and cell proliferation are modulated by the calcium sensing receptor $(\mathrm{CaR})$, the effect of $\mathrm{CaR}$ activation by the selective $\mathrm{CaR}$ agonists gadolinium $(300 \mu \mathrm{M})$ and neomycin $(1 \mathrm{mM})$ on NF- $\mathrm{KB}$ activity was investigated. Both agonists induced a significant inhibition of basal and TNF $\alpha$-stimulated levels of phosphorylated p65 (Fig. 5 and data not shown).

\section{Effect of NF-kB blockade on cyclin D1 expression}

In eight tumoral parathyroid cell preparations cultured in medium supplemented with $10 \%$ FCS, the blockade of NF- $\kappa$ B activity by incubation with $10 \mu \mathrm{M}$ BAY117082 significantly reduced FCS-stimulated cyclin D1 levels (Fig. 6). Conversely, although $100 \mathrm{ng} / \mathrm{ml} \mathrm{TNF} \alpha$ did not exert any significant effect on basal cyclin D1

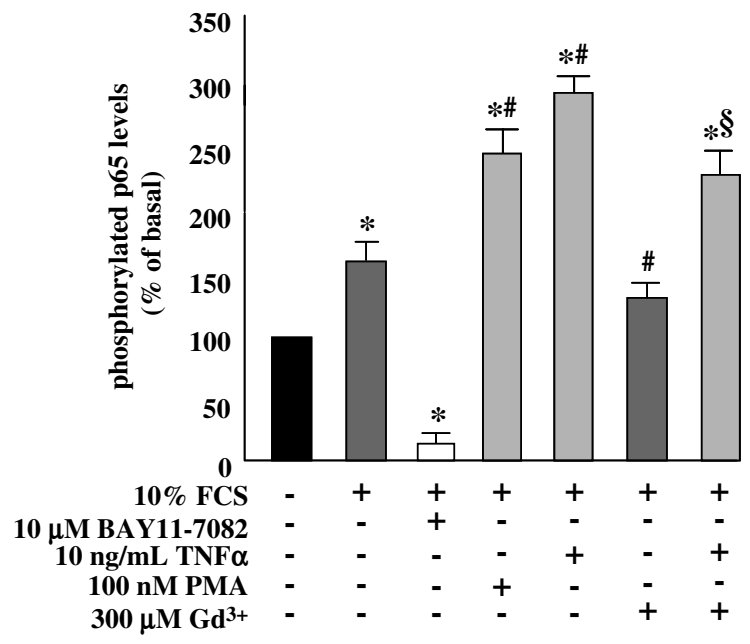

Figure 5 Phosphorylated p65 levels from nuclear extracts of human parathyroid cells treated with different stimuli for $30 \mathrm{~min}$. Stimulation with $10 \%$ FCS induced a slight but significant increase in phosphorylated p65 levels. In this condition, the blockade of NF-KB activation obtained by preincubation with the specific inhibitor BAY11-7082 $(10 \mu \mathrm{M}, n=4)$ demonstrated the specificity of the reaction and the activation of the NF- $\mathrm{KB}$ inhibitory protein I $\mathrm{KB} \alpha$. NF- $\kappa \mathrm{B}$ activity was increased by PMA $(100 \mu \mathrm{M}, n=3)$ and TNF $\alpha(100 \mathrm{ng} / \mathrm{ml}, n=4)$. CaR activation by $300 \mu \mathrm{M}$ gadolinium $\left(\mathrm{Gd}^{3+}\right)$ induced a decrease in NF- $\kappa \mathrm{B}$ activity in the basal and TNF $\alpha$-stimulated condition $(n=3)$. Data represent the percent stimulation (means \pm S.E.) over basal values (in the absence of FCS), which are arbitrarily defined as $100 \%$. ${ }^{*} P<0.05$ vs basal phosphorylated p65 levels; $\# P<0.05$ vs $10 \%$ FCS-stimulated phosphorylated p65 levels; $\S P<0.05$ vs TNF $\alpha$-stimulated phosphorylated $p 65$ levels.

expression, it induced a trend towards an increase in FCS-stimulated cyclin D1 levels $(245 \pm 57 \%, P=$ not significant). In the presence of $10 \%$ FCS, CaR activation by $300 \mu \mathrm{M}$ gadolinium induced a $22-50 \%$ reduction in cyclin D1 expression. The effects of $\mathrm{CaR}$ and BAY11-7082 on cyclin D1 were not additive, since by blocking NF- $\mathrm{KB}$ phosphorylation, $\mathrm{CaR}$ activation did not induce a further inhibition of cyclin D1 levels (Fig. 6).

\section{Discussion}

In the present study, we provided data demonstrating that the NF- $\mathrm{BB}$ pathway was active in human parathyroid cells and was likely involved to a certain extent in parathyroid cell proliferation. The transcription factor NF- $\mathrm{KB}$ is considered as a positive mediator of cell growth in a number of cell types, although the molecular mechanisms involved in this process remain largely unknown. Moreover, deregulated NF-кB 


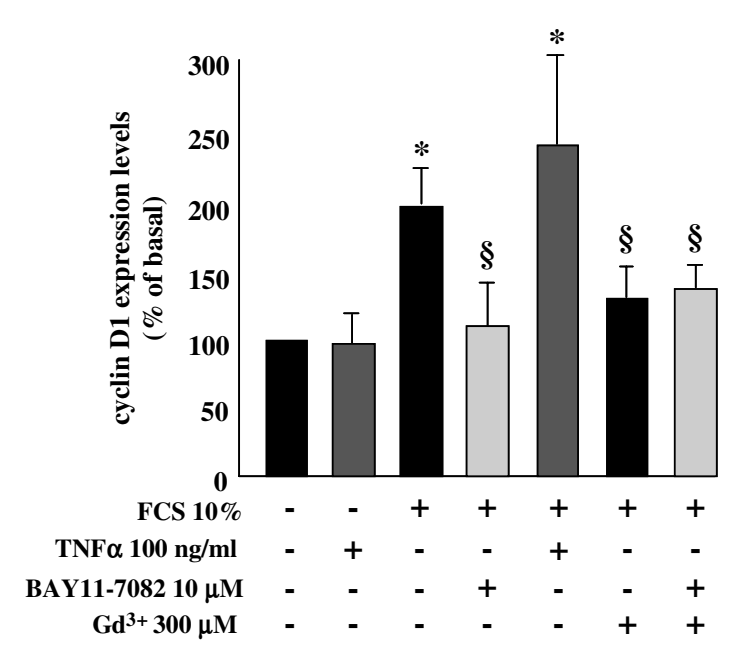

Figure 6 Modulation of cyclin D1 expression levels by the NF- $\mathrm{kB}$ pathway in tumoral parathyroid cells. Although the stimulation by TNF $\alpha(100 \mathrm{ng} / \mathrm{ml})$ did not exert significant changes in basal cyclin D1 expression levels, it induced a trend towards an increase in 10\% FCS-stimulated cyclin D1 levels $(n=3)$. Incubation with the specific inhibitor BAY11-7082 $(10 \mu \mathrm{M})$ induced a reduction in $10 \%$ FCS-stimulated cyclin D1 expression levels $(n=8)$. In the presence of FCS, the CaR activation by $300 \mu \mathrm{M}$ gadolinium $\left(\mathrm{Gd}^{3+}\right)$ induced a $22-50 \%$ reduction in cyclin D1 expression. The effects of $\mathrm{CaR}$ and BAY11-7082 on cyclin D1 were not additive, since by blocking NF- $\kappa$ B phosphorylation, CaR activation did not induce a further inhibition of cyclin D1 levels $(n=4)$. Data represent the percent variation (means \pm S.E.) over basal values, which are arbitrarily defined as $100 \%$. ${ }^{*} P<0.05$ vs basal cyclin D1 levels;

$\S P<0.05$ vs $10 \%$ FCS-stimulated cyclin D1 levels.

activity has been associated with oncogenesis, since elevated NF- $\kappa$ B levels have been described in human cancers (Dejardin et al. 1995, Sovak et al. 1997). In the present series, most of the parathyroid tumors showed reduced NF- $\mathrm{KB}$ activity with respect to normal parathyroid tissue, probably reflecting the benign feature and the low proliferative rate of these lesions. Interestingly, parathyroid hyperplasia from three MEN2A patients harboring a classic Cys634Arg RET mutation showed increased p65 phosphorylation, suggesting the presence of a constitutive NF- $\mathrm{KB}$ activation. This finding was consistent with the recent observation that RET mutations responsible for MEN2A and MEN2B induced a constitutive activation of the NF- $\kappa \mathrm{B}$ pathway in the TT cell line and $\mathrm{C}$ cell carcinomas (Ludwig et al. 2001). In the TT cell line, NF- $\kappa \mathrm{B}$ was required for RET-mediated transformation, providing the up-regulation of an antiapoptotic gene expression program and promoting cell growth. Although obtained in few lesions due to the rarity of the disorder, the data here reported suggested that NF- $\kappa \mathrm{B}$ might represent a target for RET signaling in human parathyroid cells.

Familial and sporadic parathyroid tumors are often associated with loss of the oncosuppressor function of the MEN1 gene, that is mutated in the MEN1 syndrome. It has recently been demonstrated that in the COS-7, HeLa and NTERA-2 cell lines NF-kB proteins interacted with menin both in vivo and in vitro, suggesting that modulation of $\mathrm{NF}-\kappa \mathrm{B}$ transactivation may contribute to the tumor suppressor function of menin (Heppner et al. 2001). In agreement with the only study reporting that in sporadic parathyroid adenomas menin was consistently expressed and not down-regulated as in MEN1 parathyroid samples (Bhuyan et al. 2000), in our series menin protein was detected in all tumors at highly variable levels. Interestingly, sporadic parathyroid tumors with the highest levels of menin showed the lowest levels of phosphorylated p65, suggesting the existence of an interaction between these transcription factors in parathyroid tumors. In this respect, it is tempting to speculate that in parathyroid tumors menin may act as a suppressor of the proliferative and antiapoptotic actions of the NF-kB pathway.

We have provided some insight into the role of $\mathrm{NF}-\kappa \mathrm{B}$ in human parathyroid cells. NF- $\mathrm{B}$ is maintained in an inactive form by sequestration in the cytoplasm through interaction with a family of

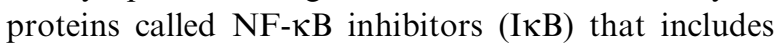
several structurally related members (Karin \& BenNeriah 2000). Proteolytic degradation of $I \kappa B$, that is rapidly induced by activators such as cytokines, toxins and mitogens, is the irreversible step required for $\mathrm{NF}-\kappa \mathrm{B}$ nuclear translocation and transcriptional activation (Karin \& Ben-Neriah 2000). We demonstrated that basal phosphorylated p65 activity detected in normal and tumoral parathyroid tissues was mainly determined by the activation of $\mathrm{I} \kappa \mathrm{B} \alpha$, as preincubation with a specific inhibitor, such as BAY11-7082, which prevents the phosphorylation of inhibitory

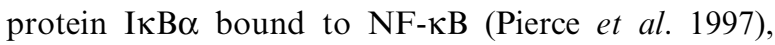
completely abolished basal phosphorylated p65 levels.

This study first reported that both mitogens and cytokines caused NF- $\kappa \mathrm{B}$ pathway activation in parathyroid cells. In particular, as observed in other cell systems, NF- $\mathrm{KB}$ activation was induced by the aspecific mitogen, PMA, known to act through protein kinase $\mathrm{C}$. Moreover, a similar activation was induced by $\mathrm{TNF} \alpha$, a cytokine not previously implicated in the control of parathyroid function or growth. Activation of NF- $\kappa \mathrm{B}$ by $\mathrm{TNF} \alpha$ requires $\mathrm{TNF} \alpha$ binding to and trimerization of its type 1 receptor that by recruiting a 
complex set of proteins induces the interaction with the large multi-protein kinase complex regulating NF- $\kappa \mathrm{B}$ activity (Aggarwal 2003). Although expression studies of these proteins in parathyroid tissues are not available, the present data showed that the TNF $\alpha$ mediated signaling pathway was operative in parathyroid cells. Therefore, although the impact of increased TNF $\alpha$ levels found in patients with primary hyperparathyroidism has previously been focused on bone resorption (Grey et al. 1996, Santos et al. 2003), the present results suggest that the parathyroid might represent a new target for $\mathrm{TNF} \alpha$ action.

Parathyroid cells are characterized by a peculiar sensitivity to extracellular calcium concentrations that is mediated by the CaR (Chen \& Goodman 2004). Recent studies showing parathyroid hyperplasia in mice and patients with inactivating mutations of the $\mathrm{CaR}$ strongly support the view that this receptor may play a pivotal role in parathyroid cell growth (Chen \& Goodman 2004). Consistent with this hypothesis, $\mathrm{CaR}$ activation by the $\mathrm{CaR}$ agonists gadolinium and neomycin induced a slight but significant decrease in both basal and TNF $\alpha$-stimulated phosphorylated p65 levels in parathyroid tumors. This observation, together with the finding that these agents significantly reduced cyclin D1 expression, provided additional evidence for the anti-proliferative role of CaR activation in parathyroid cells. The interaction between the $\mathrm{NF}-\kappa \mathrm{B}$ pathway and $\mathrm{CaR}$ signaling has recently been demonstrated in animal models, in which the induction of $\mathrm{CaR}$ expression by interleukin- $1 \beta$ was found to be mediated by the activation of the NF- $\mathrm{BB}$ pathway (Canaff \& Hendy 2005).

Finally, we investigated the effects of NF- $\kappa \mathrm{B}$ pathway activation on parathyroid cell proliferation by evaluating the expression of the cyclin D1 gene, a key regulator of $\mathrm{G} 1$ phase progression. Cyclin D1 has been demonstrated to play a key role in parathyroid cell proliferation as mice bearing a selective parathyroid overexpression of the cyclin D1 gene develop parathyroid hyperplasia associated with primary hyperparathyroidism (Imanishi et al. 2001). Moreover, the p65 subunit is a potent transcriptional activator of the cyclin D1 gene in different cell types (Guttridge et al. 1999). Indeed, NF- $\kappa B$ activity is required for cyclin D1 transcriptional initiation and hyperphosphorylation of $\mathrm{pRb}$, leading to cell cycle progression into $\mathrm{S}$ phase. The present study showed that, although cyclin D1 expression was poorly induced by TNF $\alpha$, the blockade of NF- $\kappa \mathrm{B}$ by the specific I $\kappa \mathrm{B} \alpha$ inhibitor resulted in a dramatic reduction in cyclin D1 expression, suggesting that the NF- $\kappa \mathrm{B}$ pathway may contribute to define basal cyclin D1 expression in parathyroid tumors.
In agreement with the anti-proliferative effect of $\mathrm{CaR}$ activation, $\mathrm{CaR}$ agonists caused a significant inhibition of cyclin D1 expression. This effect seemed to be, at least in part, due to the CaR-mediated inhibition of the $\mathrm{NF}-\kappa \mathrm{B}$ pathway since the effects of $\mathrm{CaR}$ agonist and $\mathrm{I} \kappa \mathrm{B} \alpha$ inhibitor on cyclin D1 were not additive. Indeed, the intracellular signals mediating the antiproliferative action of $\mathrm{CaR}$ in the parathyroid are still unknown, since the pathways so far characterized are related to cell types, such as rat osteoblasts (Chattopadhyay et al. 2004), rat H-500 Leydig cancer cells (Tfelt-Hansen et al. 2004), and ovarian surface epithelial cells (Bilderback et al. 2002), in which calcium acts as a mitogen by activating the JNK, p38 and phosphatidylinositol 3-kinase pathways respectively. The data provided here suggest that the inhibition of the proliferative NF- $\kappa \mathrm{B}$ pathway may participate, at least in part, in the control of parathyroid cell growth by $\mathrm{CaR}$ agonists.

In conclusion, the study showed that p65 phosphorylation was dramatically increased in parathyroid cells with RET constitutive activation. In sporadic parathyroid tumors p65 phosphorylation negatively correlated with menin expression. Moreover, general activators of the NF- $\mathrm{KB}$ pathway, such as PMA and $\mathrm{TNF} \alpha$, as well as specific inhibitors of parathyroid function and growth, such as CaR agonists, were effective in increasing and reducing p65 phosphorylation respectively. Finally, the observation that NF- $\mathrm{BB}$ blockade resulted in a reduction in cyclin D1 expression suggested a proliferative role for $N F-\kappa B$ in parathyroid cells.

\section{Acknowledgements}

This work was partially supported by Ricerca Corrente Funds of Ospedale Maggiore IRCCS, Milan. We are indebted to Dr U Verga and Dr Arrigoni for the supply of MEN2A parathyroid tissue samples. The authors declare that there is no conflict of interest that would prejudice the impartiality of this scientific work.

\section{References}

Aggarwal BB 2003 Signalling pathways of the TNF superfamily: a double-edged sword. Nature Reviews in Immunology 3 745-756.

Bargou RC, Emmerich F, Krappmann D, Bommert K, Mapara MY, Arnold W, Royer HD, Grinstein E, Greiner A, Scheidereit C \& Dorken B 1997 Constitutive nuclear factor-kappaB-RelA activation is required for proliferation and survival of Hodgkin's disease tumor cells. Journal of Clinical Investigation $\mathbf{1 0 0}$ 2961-2969. 
Bertolino P, Tong WM, Galendo D, Wang ZQ \& Zhang CX 2003 Heterozygous Men1 mutant mice develop a range of endocrine tumors mimicking multiple endocrine neoplasia type 1. Molecular Endocrinology 17 1880-1892.

Bhuyan MMR, Sato M, Murao K, Imachi H, Namihira H \& Takahara J 2000 Expression of menin in parathyroid tumors. Journal of Clinical Endocrinology and Metabolism 85 2615-2619.

Bilderback TR, Lee F, Auersperg N \& Rodland KD 2002 Phosphatidylinositol 3-kinase-dependent, MEKindependent proliferation in response to CaR activation. American Journal of Physiology and Cellular Physiology 283 C282-C288.

Canaff L \& Hendy GN 2005 Calcium-sensing receptor gene transcription is up-regulated by the pro-inflammatory cytokine, interleukin-1 $\beta$. Journal of Biological Chemistry 28014 177-14 188.

Chattopadhyay N, Yano S, Tfelt-Hansen J, Rooney P, Kanuparthi D, Bandyopadhyay S, Ren X, Terwilliger E \& Brown EM 2004 Mitogenic action of calcium-sensing receptor on rat calvarian osteoblasts. Endocrinology 145 3451-3462.

Chen RA \& Goodman WG 2004 Role of the calcium-sensing receptor in parathyroid gland physiology. American Journal of Physiology and Renal Physiology 286 F1005-F1011.

Corbetta S, Mantovani G, Lania A, Borgato S, Vicentini L, Beretta E, Faglia G, Di Blasio AM \& Spada A 2000 Calcium-sensing receptor expression and signalling in human parathyroid adenomas and primary hyperplasia. Clinical Endocrinology 52 339-348.

Corbetta S, Lania A, Filopanti M, Vicentini L, Ballarè E \& Spada A 2002 Mitogen-activated protein kinase cascade in human normal and tumoral parathyroid cells. Journal of Clinical Endocrinology and Metabolism 87 2201-2205.

Dejardin E, Bonizzi G, Bellahcene A, Castronovo V, Merville MP \& Bours V 1995 Highly expressed p100/p52 (NFKB2) sequesters other NF-kappaB-related proteins in the cytoplasm of human breast cancer cells. Oncogenetics 11 1835-1841.

Delfino P \& Walker WH 1999 Hormonal regulation of the $\mathrm{NF}-\kappa \mathrm{B}$ signaling pathway. Molecular and Cellular Endocrinology 157 1-9.

Fugazzola L, Cerutti N, Mannavola D, Ghilardi G, Alberti L, Romoli R \& Beck-Peccoz P 2002 Multigenerational familial medullary thyroid cancer (FMTC): evidence for FMTC phenocopies and association with papillary thyroid cancer. Clinical Endocrinology 56 53-63.

Grey A, Mitnick MA, Shapses S, Ellison A, Gundberg C \& Insogna K 1996 Circulating levels of interleukin-6 and tumor necrosis factor-alpha are elevated in primary hyperparathyroidism and correlate with markers of bone resorption - a clinical research center study. Journal of Clinical Endocrinology and Metabolism 81 3450-3454.

Guttridge DC, Albanese C, Reuther JY, Pestell RG \& Baldwin AS Jr 1999 NF-KB controls cell growth and differentiation through transcriptional regulation of cyclin D1. Molecular and Cellular Biology 19 5785-5799.

Heppner C, Bilimoria KY, Agarwal SK, Kester M, Whitty LJ, Guru SC, Chandrasekharappa SC, Collins FS, Spiegel AM, Marx SJ \& Burns AL 2001 The tumor suppressor protein menin interacts with $\mathrm{NF}-\kappa \mathrm{B}$ proteins and inhibits NF- $\mathrm{B}$ mediated transactivation. Oncogene 20 4917-4925.

Imanishi Y, Hosokawa Y, Yoshimoto K, Schipani E, Mallva S, Papanikolaou A, Kifor O, Tokura T, Sablosky M, Ledgard F, Gronowicz G, Wang TC, Schmidt EV, Hall C, Brown EM, Bronson R \& Arnold A 2001 Primary hyperparathyroidism caused by parathyroid-targeted overexpression of cyclin D1 in transgenic mice. Journal of Clinical Investigation 107 1093-1102.

Izban KF, Ergin M, Qin JZ, Martinez RL, Pooley RJ Jr, Saeed S \& Alkan S 2000 Constitutive expression of NF-kappaB is a characteristic feature of mycosis fungoides: implications for apoptosis resistance and pathogenesis. Human Pathology 31 1482-1490.

Karin M \& Ben-Neriah Y 2000 Phosphorylation meets ubiquitination: the control of NF-KB activity. Annual Reviews of Immunology 18 621-663.

Lania A, Filopanti M, Corbetta S, Ballarè E, Losa M, Beck-Peccoz P \& Spada A 2003 Effects of hypothalamic neuropeptides on extracellular signal-regulated kinase (ERK1 and ERK2) cascade in human tumoral pituitary cells. Journal of Clinical Endocrinology and Metabolism 88 1692-1696.

Libutti SK, Crabtree JS, Lorang D, Burns AL, Mazzanti C, Hewitt SM, O'Connor S, Ward JM, Emmert-Buck MR, Remaley A, Miller M, Turner E, Alexander HR, Arnold A, Marx SJ, Collins FS \& Spiegel AM 2003 Parathyroid gland-specific deletion of the mouse Men1 gene results in parathyroid neoplasia and hypercalcemic hyperparathyroidism. Cancer Research $638022-8028$.

Ludwig L, Kessler H, Wagner M, Hoang-Vu C, Dralle H, Adler G, Bohm BO \& Schmid RM 2001 Nuclear factorkappaB is constitutively active in C-cell carcinoma and required for RET-induced transformation. Cancer Research 61 4526-4535.

Pierce JW, Schoenleber R, Jesmok G, Best J, Moore SA, Collins T \& Gerritsen ME 1997 Novel inhibitors of cytokine-induced $\mathrm{I} \kappa \mathrm{B} \alpha$ phosphorylation and endothelial cell adhesion molecule expression show anti-inflammatory effects in vivo. Journal of Biological Chemistry $\mathbf{3 4}$ $21096-21103$.

Rosenberg CL, Kim HG, Shows TB, Kronenberg HM \& Arnold A 1991 Rearrangement and overexpression of D11S287E, a candidate oncogene on chromosome 11 q13 in benign parathyroid tumors. Oncogene 6 449-453.

Santos FR, Moyses RM, Montenegro FL, Jorgetti V \& Noronha IL 2003 IL-1beta, TNF-alpha, TGF-beta, and bFGF expression in bone biopsies before and 
after parathyroidectomy. Kidney International $\mathbf{6 3}$ 899-907.

Sovak MA, Bellas RE, Kim DW, Zanieski GJ, Rogers AE, Traish AM \& Sonenshein GE 1997 Aberrant nuclear factor kappaB/Rel expression and the pathogenesis of breast cancer. Journal of Clinical Investigation $1002952-2960$.

Tai DI, Tsai SL, Chang YH, Huang SN, Chen TC, Chang KS \& Liaw YF 2000 Constitutive activation of nuclear factor kappaB in hepatocellular carcinoma. Cancer 89 2274-2281.

Tfelt-Hansen J, Chattopadhyay N, Yano S, Kanuparthi D, Rooney P, Schwarz P \& Brown EM 2004 Calcium-sensing receptor induces proliferation through p38 mitogenactivated protein kinase and phosphatidylinositol 3-kinase but not extracellular regulated kinase in a model of humoral hypercalcemia of malignancy. Endocrinology 145 1211-1217. 
